\title{
The Inferred Determinants of Employees' Turnover Intention: A Comparison between Japanese and Foreign-Owned Firms in Japan
}

\author{
Rei Hasegawa ${ }^{1}$, Shinji Hasegawa ${ }^{2} \&$ Takashi Akiyama ${ }^{3}$ \\ ${ }^{1}$ Department of Business Administration, Daito Bunka University, Japan \\ ${ }^{2}$ Faculty of Social Sciences, Waseda University, Japan \\ ${ }^{3}$ Faculty of Sociology, Kansai University, Japan \\ Correspondence: Rei Hasegawa, Daito Bunka University, Department of Business Administration, Japan. E-mail: \\ reihgw@gmail.com
}

Received: April 16, 2021

Accepted: June 5, 2021

Online Published: July 12, 2021

doi:10.5539/ijbm.v16n8p96

URL: https://doi.org/10.5539/ijbm.v16n8p96

\begin{abstract}
This study compares the factors that are inferred to directly and indirectly influence the process of determining employees' turnover intention in Japan. This study focuses on the differences made by firm type, that is, Japanese firms vs. foreign-owned or foreign-affiliated firms. Multiple-group structural equation modeling was attempted by applying factors such as perceived organizational support, the positiveness of a worker, firm-specific skills, organizational commitment, perception of career opportunities within the current firm and in other firms, and turnover intention. It was found that the inferred determinants of turnover intention differed by firm type; specifically, career prospects, either internal or external, do not directly affect turnover intention in Japanese firms. For workers in foreign firms, positivity is significantly higher than that of Japanese firms. Positivity plays a crucial role in both firms; moreover, our study provides supporting evidence of the existence of sub-markets in Japan and shows that the transition of workers from foreign-owned to Japanese firms might be rare.
\end{abstract}

Keywords: employee turnover intention, Japanese-style management, multiple-group structural equation modeling, labor market

\section{Background}

Japan banned foreign direct investment until it joined the Organisation for Economic Co-operation and Development (OECD) in 1964. Since then, capital liberalization has been promoted in stages, but currently, inward direct investment is overwhelmingly smaller than that of Japanese companies' outward direct investment. At the end of 2018, Japan's inward foreign direct investment balance was less than $6 \%$ of the gross domestic product (GDP). The United States was more than 30\%, and the United Kingdom was more than $60 \%$. This has led to criticism of the low acceptance of foreign capital in Japan from other countries. For foreign companies to succeed in the Japanese market, they must overcome fierce competition in the domestic market, respond appropriately to the business practices that have been established and prevailing in the Japanese market, and meet the high level of consumer demand globally recognized. (Cabinet Office [CAO], 2008; Hasegawa, 2001; OECD, 2006).

Japanese-style management has contributed to building barriers for foreign firms to enter the Japanese market because it provides Japanese firms with a competitive advantage that some researchers have pointed out the effectiveness of human resource management (HRM) within the Japanese context, as human resources are difficult to replicate because of their embeddedness, path dependence, and tacitness (Wright, McMahan, \& McWilliams, 1994).

The HRM practices of Japanese corporations differ in many ways from the HRM practices of Western corporations (Dore, 1977; Iwata, 1987, 1973). Life-time or long-term employment, wage systems based on seniority, and within-firm labor unions are well-known characteristics (Abegglen, 1958). Other features include the simultaneous recruitment of new graduates (Japan Institute of Labour [JIL], 2001; Honda, 2010) and skills and/or competencies imparted via in-house experience and so-called on-the-job training (Koike, 1996; Koike \& Inoki, 2002). This distinctiveness results in employees' sense of belonging to their employer (Nakane, 1972) and 
a sense of commitment to the organization (Takezawa \& Whitehill, 1983). Their intention to leave the company is reduced because changing jobs often worsens their working conditions (e.g., pay, rank, and job security) and they lose their organization-specific assets (Inoki, 2001; Mincer \& Higuchi, 1988; Ono, 1995). Thus, Japan has a low voluntary job turnover rate (OECD, 1996; Blinder \& Krueger, 1996).

Turning to foreign-owned enterprises, HRM systems applied in Japan face difficulties in two main ways: isomorphism and lateness of entering (Yoshihara, 1994). There are four types of isomorphism mechanisms (DiMaggio \& Powell, 1983): 1) "local isomorphism", meaning the pressure to adapt to the business environment of the local market, 2) "corporate isomorphism", which encourages it to operate in line with its headquarters, 3) "cross-national isomorphism", which is influenced by environmental factors in the home nation, and 4) "global inter-corporate isomorphism", which refers to the imitating effect or abilities obtained by learning from the competition at the global level (Ferner \& Quintanilla, 1998). Foreign companies were latecomers in the Japanese market due to the foreign capital regulation policy adopted by the Japanese government after World War II. The full-scale entry of foreign companies began in the latter half of the 1970s. This delay in entry placed foreign firms under the condition of "liability of foreignness' (Hymer, 1960; Zaheer, 1995) and coupled with the "liability of lateness," they faced difficulties in procuring talented workers. For instance, wage premiums were often offered compared with their local rivals to recruit eligible Japanese personnel (Spence, 1973). Foreign firms could choose to differentiate their HRM system so as not to put this situation at a disadvantage. This interpretation may support the contention of Pudelko and Harzing (2008) based on the survey results covering American and German firms in Japan, concluding that foreign firms did not choose to assimilate into the Japanese HRM method.

It is expected that Japanese workers do not always take a positive view of moving between two types of companies with different HRM systems (Ono, 2007). Company expectations for employees may differ in behavioral patterns, including job involvement, commitment to the organization, and/or personal traits (Aoki, 1988; Koike, 1996; Ono, 1989). Workers would relocate from a Japanese to a foreign firm since a foreign firm generally pays more than a Japanese firm; however, this is not always the case. A worker shifting from a Japanese firm to a foreign firm and then returning to work for a Japanese firm is difficult (Ono, 2007). It is possible to grasp whether the Japanese labor market is divided or consists of two sub-markets of quite different sizes (Hasegawa \& Hasegawa, 2016).

The purpose of this study was twofold. First, the similarities and differences in the factors influencing turnover intention were assessed by examining whether the latent variable means and structural path coefficients differ between Japanese and foreign-owned firms (Kline, 2005). As shown in Section 2.1, turnover intention was used as a proxy variable for actual turnover in this study, and multiple-group structural equation modeling (SEM) was executed. By imposing the same structure on different groups (i.e., setting the same hypotheses), a standard model was tested for the full sample as well as for subsamples of the employees of Japanese and foreign-owned firms. This method has advantages over separate SEM for each group because it allowed us to examine all aspects of measurement invariance and population heterogeneity (Brown, 2006; Vandenberg \& Lance, 2000). Second, we searched for evidence to determine whether Japan's labor market is segmented, as suggested by previous studies (Ono, 2007) and what caused this segmentation by elucidating the differences in the mechanisms behind employees' turnover intention between Japanese and foreign-owned firms. For this purpose, we examined employees' perceived career opportunities (PCOs) in other Japanese and foreign-owned firms outside their employers. Dividing outside opportunities in this way is a new concept introduced herein and the main novelty of our study. This approach would work less well in Western countries, where differences in management styles between domestic firms and foreign-owned firms are not as stark.

It was found that the inferred determinants of turnover intention differed between these types of firms. This finding may provide management implications for business practitioners to retain employees and minimize the decline in their competitive advantage by scrutinizing their personnel policies.

\section{Literature Review and Hypothesis Development}

A number of studies have been conducted on turnover/turnover intention in the fields of management and human resource management (e.g., Holtom, Michell, Lee, \& Eberly, 2008). In the current study, we followed Hom, Mitchell, Lee, and Griffeth (2012), aiming to clarify whether differences existed between workers in Japanese and foreign-affiliated firms in Japan by applying an orthodox model of job turnover. Figure 1 shows the analytical framework used in this study, which consists of three parts: 1) distal antecedents such as organizational support and positiveness, 2) attitudinal antecedents and perceptions including the firm specificity 
of skills, organizational commitment, career opportunities within and outside, and 3) turnover intention as a proxy for actual turnover.

\subsection{Turnover Intention}

Turnover intention, the dependent variable, is defined as an employee's intention to voluntarily leave the current job or employer. Voluntary turnovers may incur significant costs to the enterprise losing human capital, including temporary reduction of efficiency, pressure on remaining staff, and replacement costs. What matters is the actual turnover rather than turnover intention; however, most studies employ the latter to simplify the task (Cohen, Blake, \& Goodman, 2015). One of the meta-analyses focused on their relationship revealed only moderate correlations (Dalton, Johnson, \& Daily, 1999). Since then, workers are expected to intend turnover for some time before leaving, this kind of intention is seen as one of the best predictors and is still applied in studies (Mobley, 1977; Hom \& Griffeth, 1991; Steel, 2002; Cho \& Lewis, 2012). According to the constructs depicted in Figure 1, internal and external factors influence turnover intention. Internal factors included perceived organizational support, firm-specific skills, organizational commitment, and PCOs, while external factors included positiveness and PCOs both inside and outside the firm.

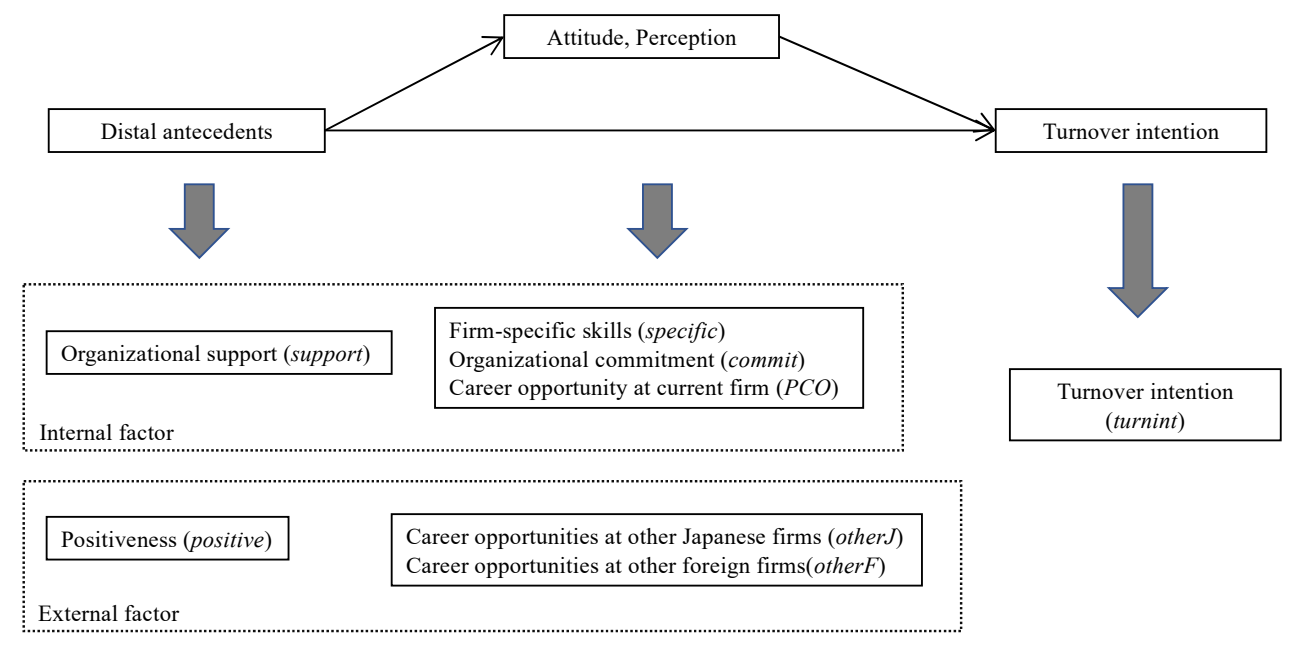

Figure 1. Framework of analysis

\subsection{Internal Factors}

Organizational support can be defined as the extent to which employees believe that their organizations evaluate their contributions fairly and correctly and try to maintain their employability of members (Eisenberger et al., 1986). On the side of the employees, comfort at the workplace and the feeling of being given discretion in ways of doing a job may be influential. Thus, a proxy for organizational support would be how much employees feel that they are expected to behave creatively.

Firm-specific skills refer to the skills that are deployable only within a given firm and thus have limited applicability outside the firm (Calunic \& Anderson, 2000; Hatch \& Dyer, 2004; Kor \& Leblebici, 2005). It is specialized expertise built over time through interactions among employees of a company (Mahoney \& Kor, 2015). It can be assumed that employees are reluctant to invest in such firm-specific skills given the alternative of developing general skills (Wang, et al. 2009), and those firm-specific investments expose employees to the potential for "hold-up" problem (Williamson, 1975) by the employer once the investments are made. Firms can alleviate hold-up concerns and encourage employees to invest in firm-specific skills by exhibiting greater organizational support.

\section{H1: Organizational support is positively related to firm-specific skills.}

Social exchange theory insists that the relationship between employees and employers is based on reciprocal interdependence (Blau, 1964; Emerson, 1976). Under such circumstances, organizational support should be returned by an employee's voluntary contribution to organizational commitment (Mowday et al., 1979; Allen \& Meyer, 1990; Eisenberger et al., 2001). According to Meyer et al. (1993), organizational commitment has three types: affective, continuance, and normative. Lee and Bruvold (2003) showed that organizational support is 
positively associated with job satisfaction and affective commitment. Hence, in this study, affective commitment was used as organizational commitment in the following hypothesis:

\section{H2: Organizational support is positively related to organizational commitment.}

Employees' career opportunities should be considered in two separate concepts, namely, actual opportunities and perceived opportunities. Employees normally set their own career goals and career paths, which in turn affects their perceived career opportunities (PCOs). Therefore, PCOs should be defined as employees' perceptions of the degree of their assignments/job opportunities that match their personal career interests/goals in currently working firms (Kraimer et al., 2011). At the same time, employees' anticipation that they could enjoy the benefits supported by the HRM system contributes to raising the level of PCOs. Such benefits include not only wages and promotion, but also human relationships with their bosses or colleagues (Seibert et al., 2001). PCOs would be enhanced when employees perceive expectations by their bosses to act creatively and achieve high performance (Landau \& Hammer, 1986). Thus, the following hypothesis is posited:

\section{H3: Organizational support is positively related to PCOs.}

As noted in the introduction, the firm-specific skills acquired by in-house and on-the-job training and experience tend to increase employees' sense of belongingness to firms and, thus, their commitment to the organization (Takezawa \& Whitehill, 1983). The firm-specific skills that have accumulated within the current firm provide sustained competitive advantage because they are heterogeneous, scarce, and non-imitable (Chadwick \& Dabu, 2009; Hatch \& Dyer, 2004). Tsui et al. (1997), who put forward a balanced view of employee-organization relationships, insisted that firm-specific human resources foster their trust that such investments will be reciprocated in the long term. Thus, firm-specific skills extend tenure and enhance affective commitment to the current employer through organizational socialization (Barker \& Feldman, 1990; Allen \& Meyer, 1990) and social identification (Ashforth \& Mael, 1989). There exists a psychological contract that encourages greater employee commitment (Brickson, 2005). Another notable point is the difficulty of transferring firm-specific skills from one firm to another without losing efficiency (Becker, 1964). Firm-specific skills can be utilized most efficiently and effectively in firms where they originated. Employees with firm-specific skills show a higher tendency to feel attached to their current employers (Becker, 1960; Bishop, 1977; Scholl, 1981).

Due to the prolonged recession after the burst of the bubble economy, Japanese firms have been searching for ways to secure profits by externalizing non-core workers (Japan Federation of Employers' Associations [JFEA], 1995). This has resulted in the expansion of irregular workers in Japan's labor market. Since this study is only for regular employees, it is supposed that firm-specific skills have a positive effect on organizational commitment, and the following hypothesis is posited:

\section{H4: Firm-specific skills are positively related to organizational commitment.}

Perceptions of employees' own career opportunities are not created alone. Rather, they are likely to be formed in the process of acquiring firm-specific skills (Newburry \& Thakur, 2010). Then, as they start feeling that they can enjoy using and realizing the value of their own skills in their current firm, PCOs rise. Thus, the following hypothesis is posited:

\section{H5: Firm-specific skills are positively related to PCOs.}

Employees might feel that their skills can be best utilized in the current firm (Galunic \& Anderson, 2000; Campbell et al. 2012) and it would be disadvantageous to move to another Japanese firm in which the value of their skills would not be recognized. Thus, the following hypothesis is posited:

\section{H6: Firm-specific skills are negatively related to PCOs in other Japanese firms.}

As Blau (1964) and Emerson (1976) viewed social exchange theory, the relationship between employees and employers shows reciprocal interdependence, suggesting that the organization offers support and that employees voluntarily show organizational commitment (Allen \& Meyer, 1990; Eisenberger et al., 2001; Mowday et al., 1979). It was further posited that this organizational commitment induced by support from the organization leads to higher estimates of employees' own PCOs in this firm. Hence, the following hypothesis is posited:

\section{H7: Organizational commitment is positively related to PCOs.}

\subsection{External Factors}

Positiveness is supposed to be one of the most desirable individual traits sought by foreign-owned firms since it suggests one's attitude and pattern of thinking at the workplace and personal life (Judge et al., 2003). It is also presumed that people with positive traits would more aggressively search for any kind of opportunity, including external PCOs, as compared to people with less positiveness and aggressiveness. Thus, the following two 
hypotheses are posited:

H8: Positiveness is positively related to PCOs in other Japanese firms.

H9: Positiveness is positively related to PCOs in other foreign-owned firms.

It is presumed that self-evaluation and confidence in one's own ability are based on the possession of general skills, which would be transferrable among Japanese and foreign-owned firms. Thus, the following two hypotheses are posited:

H10: PCOs in other Japanese firms are positively related to PCOs in other foreign-owned firms.

H11: PCOs in other foreign-owned firms are positively related to PCOs in other Japanese firms.

\subsection{Direct Effects on Turnover Intention}

A positive employee may be ambivalent in terms of turnover. Positiveness implies positive and preferable evaluations of employees' own performance, which leads to a tendency not to leave the current employers, while self-perceptions or beliefs of positive workers able to influence and control their own life, including work, may lead to the exploration of higher-level jobs regardless of the situation at the current workplace (Judge et al., 2003). Employees with high positiveness tend to look more progressively for new jobs and change their situation (Isen \& Baron, 1991; Mobley, 1977). Holtom et al. (2008) pointed out that individual differences, including personality, serve as factors to predict workers' turnover in their extensive review of research on voluntary employee turnover. Thus, positiveness can increase turnover intention, and the following hypothesis is posited:

H12: Positiveness is positively related to turnover intention.

If employees perceive that their firm-specific skills are more highly evaluated in their current firms than elsewhere, their intention to leave the firm decreases (Hauskneckt \& Holwerda, 2013; Tan \& Rider, 2017). Instead, it would be beneficial for them to stay in their current firms. Therefore, the following hypothesis is posited:

H13: Firm-specific skills are negatively related to turnover intention.

Organizational commitment is made up of three elements: 1) affective commitment, 2) continuance commitment, and 3) normative commitment. It is argued that all three components negatively influence turnover intentions through a sense of emotional attachment, attitude of avoiding cost, and perception of obligation (Mathieu \& Zajac, 1990; Meyer et al., 2002; Williams \& Hazer, 1986). Thus, the following hypothesis is posited:

H14: Organizational commitment is negatively related to turnover intention.

PCOs are presumably a crucial aspect affecting employees' quit decisions (Landau \& Hammer, 1986), with higher quit decisions likely when PCOs are low. Therefore, the following hypothesis is posited:

H15: PCOs are negatively related to turnover intention.

As PCOs in the current firm affect employees' decisions to quit or stay (Landau \& Hammer, 1986), it is assumed that the same principle applies to PCOs outside the current firm, except in the opposite direction. Thus, the following two hypotheses are posited:

H16: PCOs in other Japanese firms are positively related to turnover intention.

H17: PCOs in other foreign-affiliated firms are positively related to turnover intention.

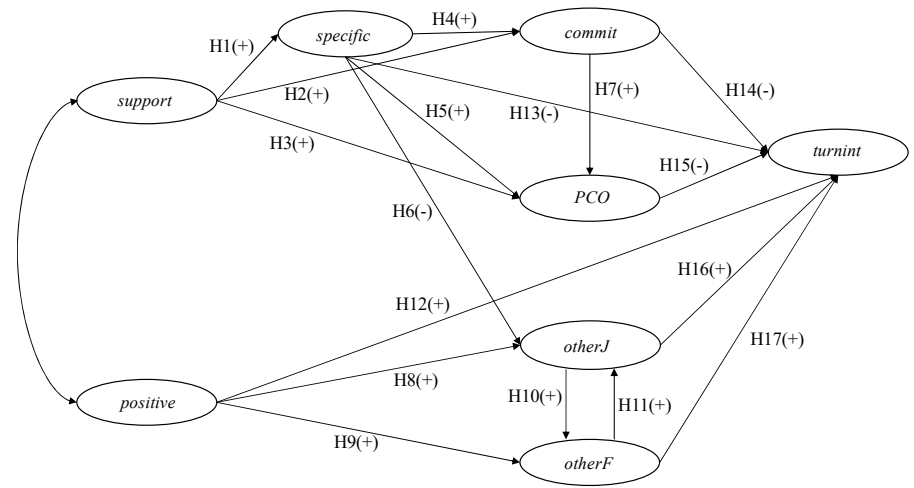

Figure 2. Hypothetical model 
Figure 2 presents the hypotheses. The factor-loading patterns were omitted to ensure clarity.

\section{Method}

\subsection{Data}

Data was collected via a web survey conducted by a research firm in February 2013 using a database of monitor members. Web surveys may have problems in terms of sample representativeness due to lack of appropriate coverage, selection bias, or treatment of non-response (Groves, 1989; Groves et al., 2009); however, supportive views on internet surveys have also been proposed, denying their absolute inferiority to various conventional manners (Ishida et al., 2009).

Starting with the online survey, random selection procedure was conducted, and 3,273 were selected from people employed by foreign-affiliated corporations and 4,288 from those employed by Japanese corporations from the database. The answers to the questionnaires were collected and presented. The questionnaires consisted of closed-ended questions with a five-point Likert scale. Of those who responded to questionnaires, 383 were usable for foreign firms and 200 for Japanese firms (response rates of $11.7 \%$ and $4.7 \%$, respectively). Figure 3 and 4 show the breakdown by sex, age, and rank.
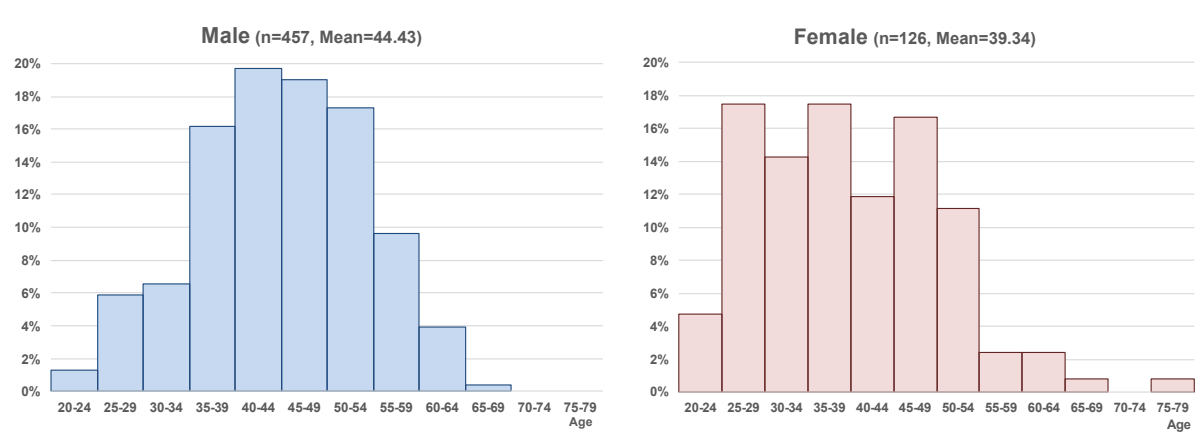

Figure 3. Breakdown by age
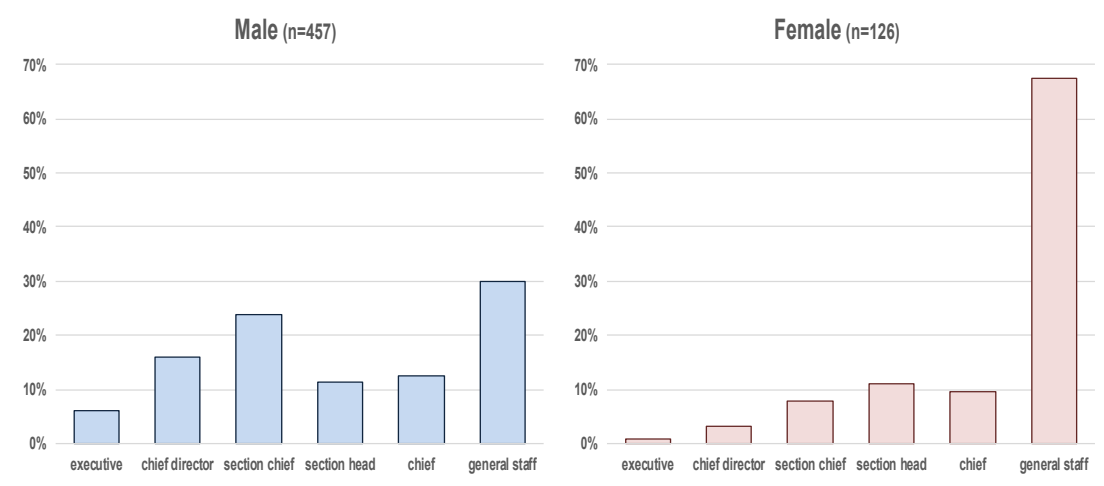

Figure 4. Breakdown by rank

Using this dataset, exploratory factor analysis was conducted with 23 observable variables and confirmed that the eight latent constructs were formed, as hypothesized. These constructs were support, positiveness, firm-specific skills, organizational commitment, PCOs in the current firm, PCOs in other Japanese firms, PCOs in other foreign-owned firms, and turnover intention. Then, a multiple-group SEM was used to compare Japanese with foreign-owned firms to analyze the hypothetical model.

\subsection{Variables}

In this section, the definitions of latent variables and the items asked in the questionnaires are discussed.

Turnover intention (turnint) is a dependent variable and is defined as the employees' intention to voluntarily leave the currently employed enterprises. Following Kelloway et al. (1999), a three-item scale is applied, including (1) I think about quitting this corporation, (2) I plan to search for another career, and (3) I do not expect to stay in this firm much longer. 
Organizational support (support) reflects what kind of behavior the firm encourages or supports for employees to take. Thus, a three-item scale were utilized as proposed by Scott and Bruce (1994), comprising the following items: (1) Creativity is encouraged here, (2) Our abilities to develop and apply new ways of doing and new ways of thinking are highly evaluated by our boss, and (3) In this organization, workers are permitted to challenge to overcome the hard situations in various methods.

Positiveness (positive) indicates employees' attitudes and patterns of thinking regarding management of their work and personal lives and applied the core self-evaluation scale (Judge et al., 2003). Particularly, three items were used, (1) Most often, I can cope with my own problems, (2) I believe that I will be successful in my life as I deserve in life, and (3) I can influence the events that will occur in my life.

As for firm-specific skills (specific), despite knowing that there are limits to how employees can accurately perceive the firm-specificity of their skills (Coff \& Raffiee, 2015), using Griffith \& Lusch (2007) and Greer et al. (2017) as references, we developed the three original questions to measure the extent to which employees perceive that their knowledge and skills can be utilized in the current employers more effectively than in others: (1) I can utilize my experience gained at this firm here and produce the best performance, (2) The skills and knowledge that I have acquired here over time will be best utilized in this firm, and (3) The human network gained in this firm and outside world can be best manifested here.

Organizational commitment (commit) is represented by two items following Meyer et al. (1993). These include (1) I feel proud to be part of this firm and (2) I personally feel that this firm offers a great deal of meaning to me.

As for the PCOs in the currently employed firm, the PCOs in other Japanese firms (otherJ), and PCOs in other foreign-owned firms (otherF), the same definition of the PCOs for three types of firms was applied, measuring how employees perceived the degree of overlapping portion between their job assignments/career opportunities and their career interests/objectives in these three types of firms, respectively. Following Kraimer et al. (2011), a three-item scale was used. The items assessed were: (1) I feel the opportunities for my further career development at this firm and I am attracted by that, (2) I feel the job opportunities are available to me in this firm and I am intrigued by that, and (3) I feel that quite a few opportunities related to my job in this firm match my career objectives. These items were used for outside firms by substituting this firm with other Japanese firms or other foreign-owned firms.

Table 1. Results of factor analysis

\begin{tabular}{|c|c|c|c|c|c|c|c|c|}
\hline & F1 & $\mathrm{F} 2$ & F3 & F4 & F5 & F6 & F7 & F8 \\
\hline \multicolumn{9}{|l|}{ F1: otherF $(\alpha=.977)$} \\
\hline career goals & 0.968 & -0.022 & -0.001 & -0.003 & -0.005 & 0.011 & -0.001 & 0.009 \\
\hline interest & 0.964 & -0.010 & -0.007 & 0.030 & -0.004 & -0.013 & 0.023 & -0.015 \\
\hline attractive & 0.962 & 0.032 & 0.017 & -0.027 & 0.010 & 0.011 & -0.028 & 0.008 \\
\hline \multicolumn{9}{|l|}{ F2: specific $(\alpha=.906)$} \\
\hline skills \& knowledge & -0.010 & 0.986 & -0.006 & -0.035 & -0.024 & -0.007 & 0.030 & -0.054 \\
\hline human network & 0.009 & 0.844 & 0.020 & 0.059 & 0.086 & -0.014 & -0.043 & -0.025 \\
\hline experience & 0.003 & 0.776 & -0.011 & 0.005 & -0.067 & 0.042 & 0.005 & 0.065 \\
\hline \multicolumn{9}{|l|}{ F3 : otherJ $(\alpha=.961)$} \\
\hline interest & -0.022 & -0.004 & 0.954 & -0.006 & 0.011 & 0.025 & 0.016 & -0.003 \\
\hline attractive & 0.021 & -0.007 & 0.937 & 0.008 & -0.011 & -0.008 & 0.002 & 0.002 \\
\hline career goals & 0.009 & 0.013 & 0.936 & -0.002 & -0.003 & -0.019 & -0.010 & 0.003 \\
\hline \multicolumn{9}{|l|}{ F4: support $(\alpha=.941)$} \\
\hline new way & -0.052 & -0.028 & 0.010 & 1.009 & 0.027 & 0.034 & -0.046 & -0.004 \\
\hline creativity & 0.021 & 0.016 & -0.005 & 0.865 & 0.012 & 0.018 & -0.020 & 0.034 \\
\hline different way & 0.039 & 0.044 & -0.006 & 0.853 & -0.056 & -0.042 & 0.081 & -0.031 \\
\hline \multicolumn{9}{|l|}{ F5: turnint $(\alpha=.941)$} \\
\hline leaving & -0.012 & -0.023 & 0.020 & 0.008 & 0.952 & -0.024 & -0.039 & 0.036 \\
\hline look for new job & -0.007 & 0.017 & 0.008 & -0.023 & 0.943 & 0.024 & -0.004 & 0.009 \\
\hline not much longer & 0.024 & 0.016 & -0.036 & 0.004 & 0.846 & -0.004 & 0.083 & -0.049 \\
\hline \multicolumn{9}{|l|}{ F6: PCO $(\alpha=.946)$} \\
\hline interest & -0.017 & 0.038 & 0.019 & -0.011 & -0.017 & 0.936 & 0.024 & -0.037 \\
\hline career goals & -0.019 & 0.018 & -0.007 & 0.016 & 0.006 & 0.922 & -0.026 & 0.008 \\
\hline attractive & 0.052 & -0.032 & -0.013 & 0.014 & 0.007 & 0.887 & 0.010 & 0.021 \\
\hline \multicolumn{9}{|l|}{ F7: positive $(\alpha=.882)$} \\
\hline coping & -0.010 & -0.032 & -0.012 & -0.029 & -0.039 & -0.035 & 0.994 & 0.024 \\
\hline confident & 0.012 & -0.039 & 0.005 & 0.039 & 0.076 & 0.017 & 0.763 & -0.006 \\
\hline determine & -0.005 & 0.070 & 0.018 & 0.004 & 0.007 & 0.034 & 0.758 & -0.016 \\
\hline \multicolumn{9}{|l|}{ F8: commit $(\alpha=.929)$} \\
\hline proud & 0.004 & 0.007 & 0.006 & 0.010 & -0.002 & 0.000 & -0.003 & 0.986 \\
\hline meaning & -0.006 & 0.213 & -0.009 & 0.035 & 0.009 & 0.055 & 0.016 & 0.667 \\
\hline Interfactor correlations & $\mathrm{F} 1$ & F2 & F3 & $\mathrm{F} 4$ & F5 & F6 & F7 & F8 \\
\hline F1 othe & - & & & & & & & \\
\hline F2 specific & 0.207 & - & & & & & & \\
\hline F3 otherJ & 0.422 & 0.306 & - & & & & & \\
\hline F4 support & 0.324 & 0.565 & 0.257 & - & & & & \\
\hline F5 turnint & 0.239 & -0.313 & 0.172 & -0.129 & - & & & \\
\hline F6 PCO & 0.429 & 0.617 & 0.328 & 0.580 & -0.186 & - & & \\
\hline F7 positive & 0.352 & 0.123 & 0.232 & 0.286 & 0.455 & 0.219 & - & \\
\hline F8 commit & 0.219 & 0.687 & 0.193 & 0.598 & -0.270 & 0.630 & 0.105 & - \\
\hline
\end{tabular}




\section{Analysis Results}

First, an exploratory factor analysis was conducted to confirm the eight theoretical constructs. These constructs are organizational support, positiveness, firm-specific skills, organizational commitment, PCOs in the current firm, PCOs in other Japanese firms, PCOs in other foreign-owned firms, and turnover intention. The extraction method adopted was maximum likelihood with promax rotation. As shown in Table 1, all 8 constructs were supported to be valid from a structural perspective.

Before applying the multiple-group structural equation modeling (SEM), the two groups must be tested separately to confirm that the hypothetical model in Figure 2 is supported for each group. This allowed us to proceed with a simultaneous multiple-group analysis. The goodness-of-fit indices were $\mathrm{CFI}=0.974$ and RMSEA $=0.057$ for Japanese firms, whereas for foreign-owned firms, CFI $=0.972$ and RMSEA $=0.056$. The results were supportive for both types of firms.

\subsection{Testing Configural Invariance}

In this study, a multiple-group SEM was used to assess the means of the eight constructs of Japanese and foreign-owned firms and the influencing patterns among these constructs for both types of firms. First, configural invariance must be tested. This means that the configurations of path diagrams should be the same for both Japanese and foreign-owned groups, having the same number of factors with the same factor loading patterns for each factor. No equality constraints were imposed on any parameter at this point. Two goodness-of-fit indices were supported (CFI=0.972, RMSEA=0.040).

\subsection{Testing Measurement Invariance}

The next step required imposing a hierarchical series of nested equality constraints on the parameters for both groups to check the goodness-of-fit indices at each step. This process was performed according to the following steps: First, as in Model 1, metric invariance was tested by setting the factor loadings to be equal for all factors in both groups. Then, as in Model 2, the factor variances and factor covariances between organizational support and positiveness were set to be equal. The third model required the factor residuals to be equal. In the fourth model, the item residuals were set to be equal. The results showed that Model 2 was the best fit (i.e., it had the smallest AIC). Thus, Model 2 was adopted to compare the latent means and parameters of the path diagrams between the two groups. The goodness-of-fit indices of Model 2 were CFI $=0.972$ and RMSEA $=0.039$.

\subsection{Testing by the Latent Mean Analysis}

Latent mean analysis was employed to compare the means of the eight latent factors. To proceed with this analysis, scalar invariance should be imposed by letting all scalar intercepts equal in both groups. A couple of goodness-of-fit indices showed acceptable results $(\mathrm{CFI}=0.972$, RMSEA $=0.039)$. The latent mean analysis cannot directly estimate the means of the latent factor or the intercepts of the latent factor. We can set these numbers for only one group to zero and allow free estimation of the other. Comparisons of means can be made between the two groups; thus, the numbers for Japanese firms were set to zero, and free estimations for foreign-owned firms were obtained.

Table 2. Results of latent mean analysis

\begin{tabular}{lcccc}
\hline & Japanese & Foreign-owned & SE & $p$ \\
\hline support & 0 & 0.535 & 0.098 & $* * *$ \\
positive & 0 & 0.385 & 0.076 & $* * *$ \\
speciifc & 0 & -0.227 & 0.085 & $* *$ \\
commit & 0 & -0.064 & 0.071 & 0.364 \\
PCO & 0 & 0.416 & 0.074 & $* * *$ \\
otherJ & 0 & 0.356 & 0.204 & 0.081 \\
otherF & 0 & 0.498 & 0.089 & $* * *$ \\
turnint & 0 & 0.020 & 0.101 & 0.846 \\
\hline note: $* * * p<.001$, & $* * p<.01, \quad * p<.05$ & &
\end{tabular}

The results are presented in Table 2 . Three of the eight factors showed no statistically significant results, namely commit, otherJ, and turnint. For four factors, namely support, positive, $P C O$, and otherF, the estimated means of foreign-affiliated firms were significantly higher than those of Japanese firms. Contrary to these results, the estimated mean score for specific was significantly lower for employees of foreign-owned firms. 


\subsection{Comparison of the Path Diagrams}

Table 3. Summary of path coefficients and hypotheses testing

\begin{tabular}{lllcccc} 
& & & \multicolumn{5}{c}{ Japanese } \\
\cline { 3 - 7 } & & & $\mathrm{B}$ & $\beta$ & $p$ & \\
\hline $\mathrm{H} 1$ & suppothesis $\rightarrow$ specific & 0.620 & 0.630 & $* * *$ & Yes \\
$\mathrm{H} 2$ & support $\rightarrow$ commit & 0.373 & 0.344 & $* * *$ & Yes \\
$\mathrm{H} 3$ & support $\rightarrow$ PCO & 0.264 & 0.288 & $* * *$ & Yes \\
$\mathrm{H} 4$ & specific $\rightarrow$ commit & 0.628 & 0.571 & $* * *$ & Yes \\
$\mathrm{H} 5$ & specific $\rightarrow$ PCO & 0.138 & 0.148 & 0.138 & No \\
$\mathrm{H} 6$ & specific $\rightarrow$ otherJ & 0.283 & 0.338 & $* * *$ & No \\
$\mathrm{H} 7$ & commit $\rightarrow$ PCO & 0.300 & 0.354 & $* * *$ & Yes \\
$\mathrm{H} 8$ & positive $\rightarrow$ otherJ & 0.298 & 0.269 & $* * *$ & Yes \\
$\mathrm{H} 9$ & positive $\rightarrow$ otherF & 0.064 & 0.050 & 0.553 & No \\
$\mathrm{H} 10$ & otherJ $\rightarrow$ otherF & 0.645 & 0.549 & $* *$ & Yes \\
$\mathrm{H} 11$ & otherF $\rightarrow$ otherJ & 0.076 & 0.089 & 0.661 & No \\
$\mathrm{H} 12$ & positive $\rightarrow$ turnint & 0.783 & 0.540 & $* * *$ & Yes \\
$\mathrm{H} 13$ & specific $\rightarrow$ turnint & -0.391 & -0.356 & $* * *$ & Yes \\
$\mathrm{H} 14$ & commit $\rightarrow$ turnint & -0.118 & -0.119 & 0.272 & No \\
$\mathrm{H} 15$ & PCO $\rightarrow$ turnint & -0.082 & -0.069 & 0.390 & No \\
$\mathrm{H} 16$ & otherJ $\rightarrow$ turnint & 0.158 & 0.121 & 0.133 & No \\
$\mathrm{H} 17$ & otherF $\rightarrow$ turnint & 0.118 & 0.106 & 0.144 & No \\
Cov & support $\leftrightarrow$ positive & 0.196 & 0.220 & $* * *$ & \\
\hline
\end{tabular}

\begin{tabular}{cccc}
\multicolumn{4}{c}{ Foreign-owned } \\
\hline $\mathrm{B}$ & $\beta$ & $p$ & \\
\hline 0.547 & 0.557 & $* * *$ & Yes \\
0.308 & 0.297 & $* * *$ & Yes \\
0.128 & 0.126 & $*$ & Yes \\
0.616 & 0.584 & $* * *$ & Yes \\
0.333 & 0.323 & $* * *$ & Yes \\
0.335 & 0.403 & $* * *$ & No \\
0.366 & 0.375 & $* * *$ & Yes \\
0.416 & 0.380 & $* *$ & Yes \\
0.268 & 0.214 & $* *$ & Yes \\
0.898 & 0.784 & $* * *$ & Yes \\
-0.643 & -0.736 & $*$ & No \\
0.561 & 0.361 & $* * *$ & Yes \\
-0.289 & -0.245 & $* *$ & Yes \\
-0.030 & -0.027 & 0.735 & No \\
-0.297 & -0.260 & $* * *$ & Yes \\
0.259 & 0.183 & $* * *$ & Yes \\
0.278 & 0.225 & $* * *$ & Yes \\
0.196 & 0.220 & $* * *$ & \\
\hline
\end{tabular}

1) B: non-standardized beta coefficient, $\beta$ : standardized beta coefficient

2) $* * * p<.001, \quad * * p<.01, \quad * p<.05$

3) Yes: hypothesis supported, No: hypothesis not supported at $p<.05$

A multiple-group SEM was performed, including latent mean analysis using Model 2, with the constraints of metric invariance, scalar invariance, and factor variances/covariances between organizational support and positiveness. Table 3 shows the path coefficients and $p$-values estimated for both groups and indicates whether each hypothesis was supported at a significance level of 0.05 . Figures 5-7 show the same information in the path diagram. In Figure 5, the hypotheses supported for both groups are indicated by solid lines and others with dotted lines, while Figure 6 (7) illustrates the results for Japanese (foreign-owned) firms, with supported hypotheses shown as solid lines and others as dotted lines.

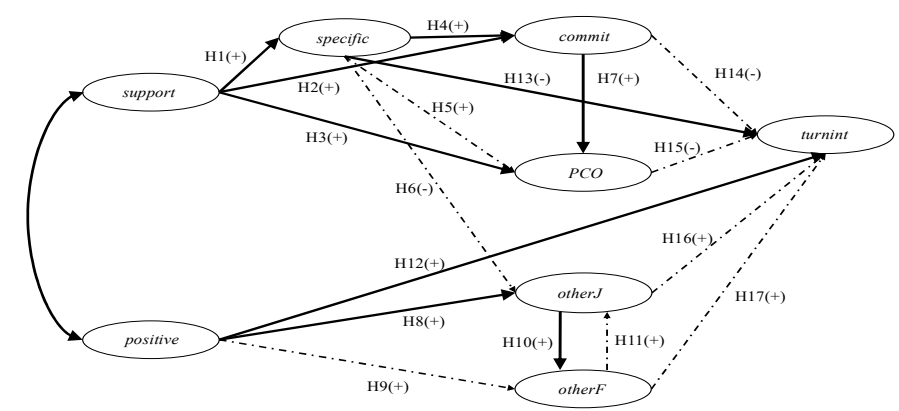

Figure 5. Hypotheses supported for both groups

Note. Hypotheses supported for both groups are shown by solid lines.

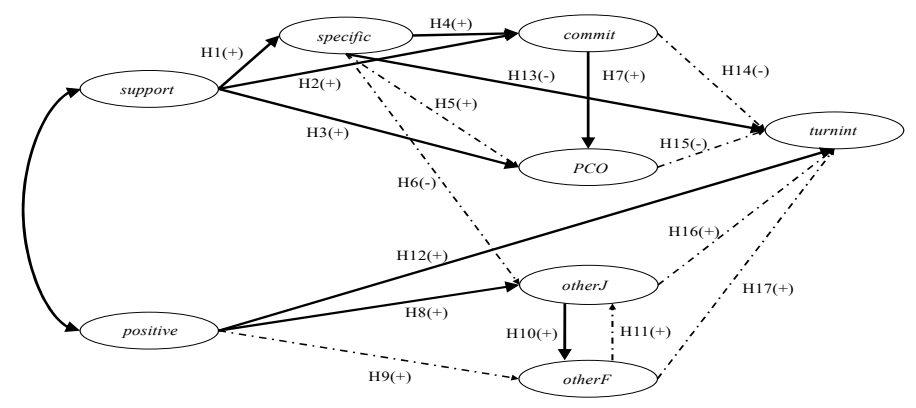

Figure 6. Results for Japanese firms

Note. Hypotheses supported are shown by solid lines. 


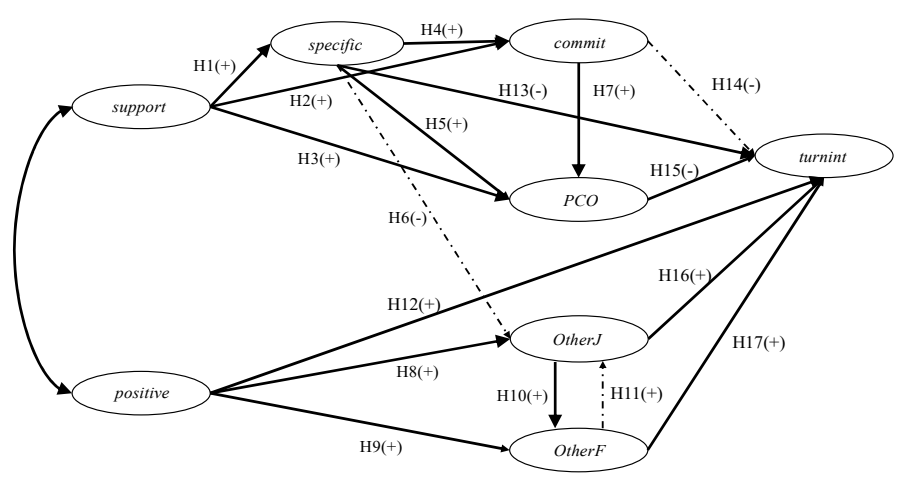

Figure 7. Results for Foreign-owned firms

Note. Hypotheses supported are shown by solid lines.

\section{Discussion}

\subsection{Analysis of Latent Mean}

As shown in Table 2, the four constructs had significantly higher estimated mean values for foreign-owned firms' employees than Japanese firms, namely, support, positive, PCO, and otherF. In contrast, specific was significantly higher for employees of Japanese firms.

Regarding support, we used employees' perceptions of being expected to behave creatively as a proxy, and it was expected that creativeness would be highly valued in Western firms based on the economic exchange theory that defines employee-organization relationships mainly of these firms (Blau, 1964). This result regarding support was in line with the initial supposition.

Positive was another factor with a significantly higher mean estimation for foreign-affiliated enterprises. It was supposed that people who work for foreign-owned firms were exposed to more severe work pressure to meet employers' expectations in the short term compared to Japanese employees; they need to think positively to survive in the workplace. This result is also in line with our expectations.

For $P C O$, the results are in line with the findings of existing studies. Hirano (2003) supported the fact that seniority-based incentives and reward systems discouraged employees' career development with self-reliance in Japanese firms. Similarly, research has found that a work environment characterized by open communication in the workplace and career support from supervisors, often seen in foreign firms, improves career prospects (House et al., 2004).

The mean difference in other $F$ was statistically significant, being higher for employees of foreign-owned firms. Regarding this result, it was conjectured that as they were actually working and knew how to work for foreign firms, they understood what types of skills were required there. Employees in Japanese firms may perceive fewer opportunities in foreign firms because of their lack of knowledge about the types of skills necessary.

Contrary to the above factors, specific was significantly higher in Japanese firms' employees. Traditionally, possessions of firm-specific skills were considered to be the critical characteristics of Japanese firms; thus, the results were consistent with our expectations. It has been argued that skills, knowledge, insight, and so forth in the workplace are more frequently fostered via on-the-job training and job rotation. These firm-specific skills increase firms' productivity and contribute to maintaining and strengthening competitive advantages (Barney \& Wright, 1998). Such knowledge is difficult for competitors to imitate because they often comprise tacit knowledge and the path-dependent accumulation process over a long period of time (Campbell et al., 2012; Koike, 2005; Sano et al., 1997). Additional expenditures are incurred for Japanese firms to invest in fostering firm-specific human capital (Hashimoto, 1981; Hashimoto \& Raisian, 1985) to sustain lifetime employment and seniority-based reward systems. Further, ethnicity and the principle of promotion from within the firm necessitate and become incentives for workers to acquire firm-specific human capital (Hanada, 1987; Koike, 2005; Moriguchi, 2014).

In addition, the three factors: commit, otherJ, and turnint, showed no significant differences. Few surveys and studies have compared turnover rates or turnover intention in domestic and foreign firms in Japan. The survey conducted by the Ministry of Economy, Trade and Industry (METI, 1997) revealed that the actual turnover rate 
of foreign-affiliated corporations is considerably lower than the turnover rate of all firms in Japan. This was true for both manufacturing and non-manufacturing sectors. Although this result was not consistent with the prevalent notions (Lincoln \& Kalleberg, 1996), it might be due to the lack of control for variables such as firm size or tenure. The present study showed no significant difference in the turnover intention of employees in Japanese and foreign-affiliated firms.

With regard to organizational commitment, employment practices specific to Japanese companies, such as long tenure, job rotation, and cooperative relationships between labor and management (Abegglen, 1958; Dore, 1973; Hirano, 2011; OECD, 1972) have been demonstrated to strengthen certain types of organizational commitment, namely affective and normative commitment (Meyer et al., 2012; Sekimoto \& Hanada, 1987). In this study, no such clear difference was found, suggesting that people's ways of working are changing (Kagono, 2010; Miyamoto, 2007). This indicates high commitment is no longer created among Japanese workers, irrespective of the types of firms for which they work.

\subsection{Comparison of the Path Diagrams}

With regard to the seventeen hypotheses shown in the path diagrams, nine hypotheses were supported in both diagrams, namely, $\mathrm{H} 1-\mathrm{H} 4, \mathrm{H} 7, \mathrm{H} 8, \mathrm{H} 10, \mathrm{H} 12$, and H13. On the contrary, H6, H11, and H14 were not supported for either group. Lastly, five hypotheses, H5, H9, and H15-H17, were only supported on the foreign-owned side. The remaining part of this discussion is divided into three sections: relationships among internal factors $(\mathrm{H} 1-\mathrm{H} 5$, and $\mathrm{H} 7)$, relationships among external factors (H6 and H8-H11), and direct effects on turnover intention (H12H17).

\subsection{Relationships Among Internal Factors}

With regard to the effects of support on specific, commit, and $P C O$, all three hypotheses H1-H3 were in accordance with the supposition for both types of firms. One practical implication of this result is that firms encourage employees to gain firm-specific skills and show organizational commitment by enhancing support from the employer to employees.

In regards to $\mathrm{H} 4$ and $\mathrm{H} 5$, the internal effect of firm-specific skills was examined and supported for both groups; $\mathrm{H} 4$ reflected the traditional view.

For $P C O, \mathrm{H} 5$ was supported only for foreign-owned firms. According to Lazear (2009), firm-specific skills come from a combination of general and specific skills. This fact suggests that it is fundamental for workers in foreign-owned firms to have general skills. If they have firm-specific skills in combination with general skills, their PCOs in their current firm may also be high. By contrast, the possession of firm-specific skills may be taken for granted in the case of Japanese firms, suggesting no strong effect on PCO.

Another factor may be related to technological innovation to explain the effect of specific on $P C O$. Technological progress in the ICT field has demanded specialized skills. Responding to such needs, the traditional way of training human resources on the job within each firm is no longer sufficient. Workers who have obtained ICT skills now readily move to other firms, imposing firms to bear the risk of losing capable personnel. ICT skills are considered job-specific, general skills rather than firm-specific skills. Some Japanese firms may hesitate to invest as much as before. The expiration period of the return on investment in human capital has declined because of the influence of the ICT revolution (Chuma, 2015). Many Japanese firms are thus putting diminishing efforts on in-house human capital formation for reasons such as strengthening financial management and declining employment security capacity (Jacoby, 2005), suggesting that firm-specific skills may contribute less to firms' performance.

The third factor may be related to the business environment. Uncertainty increased and competitive conditions are constantly changing because of emerging new technologies, new rival firms, and other factors; as a result, firms are eager to acquire strategic organizational flexibility (Sanchez, 1995). Firms must forecast these dynamic and constant changes in the competitive environment and respond in a timely manner to changes by mobilizing all strategic and management resources. Firm-specific skills are also typically accumulated in Japanese firms' production processes, called an integral production system, a coordination-intensive process (Clark \& Fujimoto, 1991).

Finally, $\mathrm{H} 7$ hypothesized a positive effect from commit to $P C O$, which was supported in the diagrams of both types of firms.

\subsection{Relationships among External Factors}

Positing a negative effect of specific on otherJ, $\mathrm{H} 6$ resulted in significant effects in the opposite direction (i.e., a 
positive relationship) for both types of firms. It was posited that the higher the firm-specific skills, the higher the PCOs in the current firm and the lower the PCOs outside the current firm, since employees' skills are not expected to be appreciated in other firms to the same degree (Coff \& Raffiee, 2015); however, a higher perception of firm-specific skills resulted in a higher perception of PCOs in other Japanese firms. It is assumed that even if their skills are firm-specific, workers feel that they can still perform well in other firms. Alternatively, workers may perceive their skills as a combination of specific and general skills, as the cluster skills theory suggests (Lazear, 2009). Firm-specific and general skills can simultaneously be perceived as high, contradicting the idea that they are in a trade-off relationship.

$\mathrm{H} 8$ hypothesized a positive effect from positive to otherJ, and $\mathrm{H} 9$ hypothesized a positive effect from positive to other $F$ and were supported for both types of firms, excluding $\mathrm{H} 9$ for Japanese firms. Foreign-owned firms in Japan typically require special or different skills for employees, such as English proficiency, positive and self-confident attitudes, creativity, specialism, a performance-based wage system, and early promotion (JFEA, 2002). Employees in Japanese firms who have never experienced such HRM systems may not expect their PCOs in other foreign-owned firms to be high, even if they are positive in general. Only those employees who have previously worked in foreign-owned firms may have high PCOs in other foreign firms. This explains why H9 was supported in the diagram of foreign-affiliated firms but not for Japanese firms.

H10, which hypothesized a positive effect from other $J$ to other $F$, was supported for both types of firms. This may be because employees' career perspectives in other Japanese firms are based on a high self-evaluation of their own capabilities. This kind of self-confidence may increase the level of PCOs in other firms, including foreign-owned firms, which is assumed to be true for both Japanese and foreign-owned firms.

H11, which hypothesized a positive effect from otherF to otherJ, was not significant for Japanese firms or, interestingly, foreign-owned firms; indeed, H11 showed a significantly negative effect. The following three interpretations of this result may be possible. First, otherF could not predict otherJ, unlike the other way around, because other $F$ requires special skills not possessed by most Japanese workers, such as language proficiency and creativity (JFEA, 2002). Second, employees working for foreign-owned firms may feel that they are evaluated fairly by their current employers, but it is uncertain whether they would be evaluated fairly in the conservative Japanese corporate culture, which appreciates seniority over individual performance (Ono, 2007). The difference in the evaluation of human capital is also consistent with the discussion on foreign ownership wage premiums (Egger \& Kreichemeier, 2013; Heyman et al., 2007; Malchow-Moller et al., 2013; Tanaka, 2015). Therefore, the higher otherF is, the lower other $J$ becomes for employees in foreign-owned firms. Third, people who appreciate the HRM practices of foreign firms are more likely to continue to look for alternative positions under the same HRM practices (Ono, 2007). The results of H11 may serve as supporting evidence that a sub-market has formed for those choosing to work for foreign-affiliated firms because of the gap in HRM systems. As a result, the Japanese labor market may be regarded as consisting of workers with two distinctive features: those employed by Japanese firms and those working for foreign-affiliated firms (Hasegawa 2018).

\subsection{Direct Effects on Turnover Intention}

H12, which hypothesized a positive effect from positive to turnint, and H13, which hypothesized a negative effect from specific to turnint, were supported for both types of firms. On the contrary, H14 hypothesized a negative effect from commit to turnint and was not supported for either Japanese or foreign-affiliated firms. Conventionally, organizational commitment has been considered to have a negative effect on turnover intention (Blau \& Boal, 1997; Mathieu \& Zajac, 1990; Mayer et al., 2002). In this study, the effects were negative as expected, but the degrees were extremely low and did not support the hypothesis for both types of firms.

Regarding the effects of PCOs inside and outside the current firm, H15-H17 were not supported for Japanese firms, whereas all of them were supported by foreign-owned firms. Overall, the effect of positiveness on turnover intention is stronger for foreign-owned firms. For Japanese firms, there was only a direct effect from positive to turnint, while indirect effects were found for foreign-owned firms to be mediated by otherJ and otherF. Moreover, Table 2 shows that the means of $P C O$, other $F$, and positive are significantly higher for foreign firms, suggesting that workers in foreign firms more aggressively pursue their own career development both within and outside the current firm.

Based on the findings of this study, we argue that it is necessary for Japanese firms to acquire the capability to effectively manage workers with abilities required by foreign-owned firms to compete globally. Japanese managers may thus need to recognize the changes that occur in the labor market and promptly adjust to it. 


\section{Conclusions}

Examining the job turnover of employees in firms in Japan, it was found that employees of Japanese and foreign-owned firms showed similar patterns, suggesting that the HRM systems of foreign-affiliated firms have had exposure to pressure to adopt "local isomorphism" (Ferner \& Quintanilla, 1998). Due to the necessity of local adaptation owing to the pressure to adopt local HRM systems to become locally isomorphic, foreign-affiliated firms were placed in the condition of conflict with the pressure for "corporate isomorphism." This conflict may have caused the failure to carry out their subsidiary roles, especially when the institutional distances from their home country are large (Hasegawa \& Hasegawa, 2016). In addition, because of these different pressures on foreign subsidiaries, the HRM systems in Japan currently reveal both similarities and differences with local Japanese firms.

In the Japanese labor market, some of these similarities have been realized because of the changing HRM systems on the side of Japanese firms. Japanese HRM systems have been, and are now, facing pressure to change, partly due to the entry of foreign firms. The institutional and strategic complementarity theory has been argued to result in resistance to changing HRM systems; however, these two types of complementarity, institutional and strategic, have been the basis for the so-called Japanese management and HRM system (Aoki, 2001). Recently, the Japanese economy has undergone a structural transformation, and Japanese firms' HRM have changed toward global standards as part of this transformation. Although the findings serve as supporting evidence for the segmentation of the labor market between two types of firms at this point, the discrepancy may actually be diminishing.

The comparison of the two groups using multiple-group SEM in this study clarified some of the differences between them. First, for those working in foreign-owned firms, the support for the existence of a relationship in the opposite direction of $\mathrm{H} 11$ represented a negative effect from otherF to otherJ and provides us with supporting evidence of the existence of sub-markets in Japan. Some workers prefer to work for foreign-owned firms because they may perceive that they possess the skills and experience required by such enterprises. Those workers may feel that Japanese firms would not appreciate their abilities, resulting in a situation where their estimates of other $J$ have become lower as they estimate other $F$ higher. This finding might suggest, as noted in the introduction, that the transition of workers from foreign-owned firms to Japanese firms is rare.

On the contrary, for those working in Japanese firms, the mean of otherF is significantly lower than that of foreign-owned firms, and the increase in other $F$ would not raise the estimate of turnover intention. Thus, it may be assumed that the possibility of moving from Japanese to other foreign firms would be low, even though the wage discrepancy may encourage such moves from Japanese firms to foreign-owned firms. All these findings serve as supporting evidence that the Japanese labor market is segmented into domestic and foreign firms.

Second, looking at the direct effects on turnover intention, $\mathrm{H} 15$ for $P C O, \mathrm{H} 16$ for otherJ, and $\mathrm{H} 17$ for otherF showed no significance for Japanese companies; however, all three showed significant effects for foreign-owned firms. The result that career prospects, either internal or external, do not directly affect turnover intention in Japanese firms may be in line with their practice of long-term or lifetime employment. On the contrary, for workers in foreign firms, the latent mean of positive is significantly higher than that in Japanese firms, and positiveness not only has a significant direct effect on turnover intention, but also has indirect effects mediated by both otherJ and otherF. Thus, positiveness plays an important role as a determinant of turnover intention. Based on H9-H11, workers in Japan still feel that Japanese and foreign-affiliated companies practice different types of HRM. Those who have worked in foreign-owned firms tend to estimate otherF higher, perhaps knowing the HRM of foreign firms. Hence, although the labor market is changing, Japanese workers may still continue to see a difference between the two types of firms.

One of the limitations of this study is that data showing the level of general skills were not employed, assuming a trade-off relationship between firm-specific and general skills. The summation of two types of skills should become $100 \%$, so that obtaining one side of information is sufficient. Employees may be able to enhance both skills simultaneously (i.e., no such trade-off exists). Considering future research, the study also recognized the need to include variables such as work/life balance as well as control variables such as gender and age, although a different method may have to be adopted to accommodate them.

Since the Japanese management style is unique among developed countries, foreign-owned firms have experienced problems when employing Japanese workers; however, little academic attention has been paid to what has occurred inside foreign-owned firms in Japan. In this research, focus was on the turnover intention by comparing two types of firms, revealing clear differences, such as the tendency to move among a particular type of firm and the influence of an individual's positiveness. 


\section{Acknowledgements}

This work was supported by JSPS KAKENHI Grant Numbers JP23330134, JP20K01836.

\section{References}

Abegglen, J. (1958). The Japanese factory: aspects of its social organization. Free Press.

Allen, N. J., \& Meyer, J. P. (1990). The measurement and antecedents of affective, continuance and normative commitment to the organization. Journal of Occupational Psychology, 63(1), 1-18. https://doi.org/10.1111/j.2044-8325.1990.tb00506.x

Aoki, M. (1988). Toward a comparative Institutional Analysis. MIT Press.

Aoki, M. (2001). Information, corporate governance, and institutional diversity: Competitiveness in Japan, the USA, and the transitional economies. Oxford University Press.

Ashforth, B. E., \& Mael, F. (1989). Social identity theory and the organization. Academy of Management Review, 14(1), 20-39. https://psycnet.apa.org/doi/10.2307/258189

Barker, H., \& Feldman, D. (1990). Strategies of organizational socialization and their impact on newcomer adjustment. Journal of Managerial Issues, 2(2), 198-212. http://www.jstor.org/stable/40603719

Barney, J. B., \& Wright, P. M. (1998). On becoming a strategic partner: The role of human resources in gaining competitive advantage. Human Resource Management, 37(1), 31-46. https://doi.org/10.1002/(SICI)1099-050X(199821)37:1\%3C31::AID-HRM4\%3E3.0.CO;2-W

Becker, H. S. (1960). Notes on the concept of commitment. American Journal of Sociology, 66(1), 32-40. http://dx.doi.org/10.1086/222820

Becker, G. S. (1964). Human capital: a theoretical and empirical analysis, with special reference to education. University of Chicago Press.

Bishop, J. H. (1997). What we know about employer-provided training: A review of the literature. Research in Labor Economics, 16, 19-87. https://hdl.handle.net/1813/77037

Blau, G. (1964). Exchange and power in social life. John Wiley and Sons.

Blau, G., \& Boal, K. B. (1987). Conceptualizing how job involvement and organizational commitment affect turnover and absenteeism. Academy of Management Review, 12(2), 288-300. https://doi.org/10.2307/258536

Blinder, A. S., \& Krueger, A. B. (1996). Labor turnover in the USA and Japan: A tale of two countries. Pacific Economic Review, 1(1), 27-57. https://doi.org/10.1111/j.1468-0106.1996.tb00173.x

Brickson, S. L. (2005). Organizational identity orientation: Forging a link between organizational identity and organizations' relations with stakeholders. Administrative Science Quarterly, 50(4), 576-609. https://doi.org/10.2189\%2Fasqu.50.4.576

Cabinet Office, Government of Japan (CAO). (2008). Factor analysis of outward and inward direct investment: why is FDI in Japan low? (in Japanese).

Campbell, B. A., Ganco, M., Franco, A. M., \& Agarwal, R. (2012). Who leaves, where to, and why worry? employee mobility, entrepreneurship and effects on source firm performance. Strategic Management Journal, 33(1), 65-87. https://doi.org/10.1002/smj.943

Chadwick, C., \& Dabu, A. (2009). Human resources, human resource management, and the competitive advantage of firms: toward a more comprehensive model of causal linkages. Organization Science, 20(1), 253-272. http://dx.doi.org/10.1287/orsc.1080.0375

Cho, Y. J., \& Lewis, G. B. (2012). Turnover intention and turnover behavior: implications for retaining federal employees. Review of Public Personnel Administration, 32(1), 4-23. https://doi.org/10.1177\%2F0734371X11408701

Chuma, H. (2015). Reconsidering Becker's human capital theory under CT/AI revolution (in Japanese). Japan Labor Review, 57(10), 66-78. https://www.jil.go.jp/institute/zassi/backnumber/2015/10/pdf/068-078.pdf

Clark, K. B., \& Fujimoto, T. (1991). Product development performance: strategy, organization, and management in the world auto industry. Harvard Business School Press.

Coff, R., \& Raffiee, J. (2015). Toward a theory of perceived firm-Specific human capital. Academy of Management Perspectives, 29(3), 326-341. http://dx.doi.org/10.5465/amp.2014.0112 
Cohen, G., Blake, R. S., \& Goodman, D. (2015). Does turnover intention matter? Evaluating the usefulness of turnover intention rate as a predictor of actual turnover rate. Review of Public Personnel Administration, 36(3), 240-263. https://doi.org/10.1177\%2F0734371X15581850

Dalton, D. R., Johnson, J. L., \& Daily, C. M. (1999). On the use of “Intent to...” variables in organizational research: an empirical and cautionary assessment. Human Relations, 52(10), 1337-1350. https://doi.org/10.1023/A:1016916632024

DiMaggio, P. J., \& Powell, W. W. (1983). The iron cage revisited: institutional isomorphism and collective rationality in organizational fields. American Sociological Review, 48(2), 147-160. https://doi.org/10.2307/2095101

Dore, R. P. (1973). British factory, Japanese factory: the origins of national diversity in industrial relations. University of California Press.

Egger, H., \& Kreickemeier, U. (2012). Why foreign ownership may be good for You. International Economic Review, 54(2), 693-716. https://doi.org/10.1111/iere.12011

Eisenberger, R., Armeli, S., Rexwinkel, B., Lynch, P. D., \& Rhoades, L. (2001). Reciprocation of perceived organizational support. Journal of Psychology, 86(1), 42-51. https://doi.org/10.1037/0021-9010.86.1.42

Eisenberger, R., Huntington, R., Hutchison, S. \& Sowa, D. (1986). Perceived organizational support. Journal of Applied Psychology, 71(3), 500-507. https://psycnet.apa.org/doi/10.1037/0021-9010.71.3.500

Emerson, R. M. (1976). Social exchange theory. Annual Review of Sociology, 2, 335-362. https://doi.org/10.1146/annurev.so.02.080176.002003

Ferner A., \& Quintanilla, J. (1998). Multinationals, national business systems and HRM: the enduring influence of national identity or a process of 'Anglo-Saxonization'. International Journal of Human Resource Management, 9(4), 710-731. https://doi.org/10.1080/095851998340973

Galunic, C., \& Anderson, E. (2000). From security to mobility: Generalized investments in human capital and agent commitment. Organization Science, 11(1), 1-20. https://doi.org/10.1287/orsc.11.1.1.12565

Greer, C. R., Lusch, R., \& Hitt, M. (2017). A service perspective for human capital resources: A critical base for strategy implementation. Academy of Management Perspectives, 31(2), 137-158. https://doi.org/10.5465/amp.2016.0004

Griffith, D. A., \& Lusch, R. F. (2007). Getting marketers to invest in firm-specific capital. Journal of Marketing, 71(1), 129-145. https://doi.org/10.1509\%2Fjmkg.71.1.129

Groves, R. M. (1989). Survey errors and survey costs. John Wiley \& Sons.

Groves, R. M., Fowler, F. J., Couper, M. P., Lepkowski, J. M., Singer, E., \& Tourangeau, R. (2009). Survey methodology (2nd ed.). Wiley.

Hanada, M. (1987). Tournament mobility of Japanese firm's promotion systems and strategic human resources management (in Japanese). Organizational Science, 21(2), 44-53.

Hasegawa, S. (2001). A surge in inward direct investment to Japan and the strategy of multinational Firms (in Japanese). World Economic Review, 45(9), 16-28.

Hasegawa, S. (2018). The era of firm globalization and human capital (in Japanese). World Economic Review, $62(2), 55-66$,

Hasegawa, S., \& Hasegawa, R. (2016). Foreign-owned firms in Japan and subsidiary role in the multinational enterprise. Working Paper Series, School of Social Sciences, Waseda University, 2015-06.

Hashimoto, M. (1981). Firm-specific human capital as a shared investment. American Economic Review, 71(3), 475-482. http://www.jstor.org/stable/1802794

Hashimoto, M., \& Raisian, J. (1985). Employment tenure and earnings profiles in Japan and the United States. American Economic Review, 75(4), 721-735. http://www.jstor.org/stable/1821350

Hatch, N. W., \& Dyer, J. H. (2004). Human capital and learning as a source of sustainable competitive advantage. Strategic Management Journal, 25(12), 1155-1178. https://doi.org/10.1002/smj.421

Hausknecht, J. P., \& Holwerda, J. A. (2013). When does employee turnover matter? Dynamic member configurations, productive capacity, and collective performance. Organization Science, 24(1), $210-225$. https://doi.org/10.1287/orsc. 1110.0720 
Heyman, F., Sjoholm, F., \& Tingvall, P. G. (2007). Is there really a foreign ownership wage premium? Evidence from matched employer-employee data. Journal of International Economics, 73(2), 355-376. https://doi.org/10.1016/j.jinteco.2007.04.003

Hirano, M. (2003). Self-reliance career development via change in organization mode of Japanese firm (in Japanese). Discussion Paper Series, Kobe University.

Hirano, M. (2011). Diversification of employment categories in Japanese firms and its functionality: a study based on the human resource portfolio system. In R. Bebenroth \& T. Kanai (Eds.), Challenges of human resource management in Japan (pp. 188-209). Routledge.

Holtom B. C., Mitchell, T. R., Lee, T. W., \& Eberly, M.B. (2008). Turnover and retention research: a glance at the past, a closer review of the present, and a venture into the future. Academy of Management Annals, 2(1), 231-274. http://dx.doi.org/10.5465/19416520802211552

Hom, P. W., \& Griffeth, R. W. (1991). A structural equations modeling test of a turnover theory: cross-sectional and longitudinal analysis. Journal of Applied Psychology, 76(3), 350-366. https://doi.org/10.1037/0021-9010.76.3.350

Hom P. W., Mitchell, T. R., Lee, T. W., \& Griffeth, R. W. (2012). Reviewing employee turnover: focusing on proximal withdrawal states and an expanded criterion. Psychological Bulletin, 138(5), 831-858. http://dx.doi.org/10.1037/a0027983

Honda, Y. (2010). Reconsidering the peculiarities of job-hunting activities of Japanese college graduates (in Japanese). In T. Kariya \& Y. Honda (Eds.), A Sociology of college graduates' employment. University of Tokyo Press.

House, R. J., Hanges, P. J., Javidan, M., Dorfman, P. W., \& Gupta, V. (2004). Culture, leadership, and organizations. Sage Publications.

Hymer, S. (1960). The international operations of national firms, a study of direct foreign investment. Thesis (Ph.D.), MIT. http://hdl.handle.net/1721.1/27375

Inoki, T. (Ed.). (2001). Economics of job-change: job selection and human resource development (in Japanese). Toyo Keizai.

Isen, A. M., \& Baron, R. A. (1991). Positive affect as a factor in organizational-behavior. Research in organizational behavior, 13, 1-53.

Ishida, H., Sato, K., Sato, H., Toyoda, Y., Hagiwara, M., Hagiwara, M., Honda, N., Maeda, Y., \& Miwa. T. (2009). Toward establishing a reliable internet survey method (in Japanese). SSJDA-42. Institute of Social Science, Univ. of Tokyo.

Itami, H. (1987). Management of humanitarianism (in Japanese). Chikuma-shobo.

Iwata, R. (1977). Principle of Japanese management system (in Japanese). Bunshindo.

Jacoby, S. M. (2005). The embedded corporation: Corporate governance and employment relations in Japan and the United States. Princeton University Press. https:/www.jstor.org/stable/j.ctv36zrn5

Japan Federation of Employers' Associations (JFEA). (1995). Japanese management in the new era (in Japanese).

JFEA. (2002). Return to origin: Direction of diversity management (in Japanese).

Japan Institute of Labour (JIL). (2001). Universities and occupations in Japan and Europe: Comparative survey results on higher education and occupation in 12 countries (in Japanese).

Judge, T. A., Erez, A., Bono, J. E., \& Thoresen, C. J. (2003). The core self-evaluations scale: development of a $\begin{array}{llll}\text { measure. } & \text { Personnel } & \text { Psychology, } & \text { 36(2), }\end{array}$ https://psycnet.apa.org/doi/10.1111/j.1744-6570.2003.tb00152.x

Kagono, T. (2010). The spirit of management: what we abandoned (in Japanese). Japan Productivity Center.

Kalleberg, A. L. (1977). Work values and job rewards: a theory of job satisfaction. American Sociological Review, 42(1), 124-146. https://doi.org/10.2307/2117735

Kelloway, E. K., Gottlieb, B. H., \& Barham, L. (1999). The source, nature, and direction of work and family conflict: a longitudinal investigation. Journal of Occupational Health Psychology, 4(4), 337-346. https://doi.org/10.1037//1076-8998.4.4.337 
Kline, R. B. (2005). Principles and practice of structural equation modeling (2nd ed.). Guilford Press.

Koike, K. (1996). The economics of works in Japan. LTCB International Library Foundation.

Koike, K., \& Inoki, T. (2002). Human resource formation in white-color workers: comparison among Japan, US, $U K$, and Germany (in Japanese). Toyo Keizai.

Kor, Y. Y., \& Leblebici, H. (2005). How do interdependencies among human-capital deployment, development, and diversification strategies affect firms' financial performance? Strategic Management Journal, 26(10), 967-985. http://dx.doi.org/10.1002/smj.485

Kraimer, M. L., Seibert, S. E., Wayne, S. J., Liden, R. C., \& Bravo, J. (2011). Antecedents and outcomes of organizational support for development: the critical role of career opportunities. Journal of Applied Psychology, 96(3), 485-500. http://dx.doi.org/10.1037/a0021452

Landau, J., \& Hammer, T. H. (1986). Clerical employees' perceptions of intraorganizational career opportunities. Academy of Management Journal, 29(2), 385-404. https://doi.org/10.2307/256194

Lazear, E. P. (2009). Firm-specific human capital: a skill-weights approach. Journal of Political Economy, 117(5), 914-940. https://doi.org/10.1086/648671

Lee, C. H., \& Bruvold, N. T. (2003). Creating value for employees: investment in employee development. International Journal of Human Resource Management, 14(6), 981-1000. https://doi.org/10.1080/0958519032000106173

Lincoln, J. R., \& Kalleberg, A. L. (1996). Commitment, quits, and work organization in Japanese and U.S. plants. Industrial and Labor Relations Review, 50(1), 39-59. https://doi.org/10.2307/2524388

Mahoney, J. T., \& Kor, Y. Y. (2015). Advancing the human capital perspective on value creation by Joining capabilities and governance approaches. Academy of Management Perspectives, 29(3), 296-308. https://doi.org/10.5465/amp.2014.0151

Malchow-Møller, N., Markusen, J. R., \& Schjerning, B. (2013). Foreign firms, domestic wages. Scandinavian Journal of Economics, 115(2), 292-325. http://www.jstor.org/stable/43673629

Mathieu, J. E., \& Zajac, D. M. (1990). A review and meta-analysis of the antecedents, correlates and consequences of organizational commitment. Psychological Bulletin, 108(2), 171-194. http://dx.doi.org/10.1037//0033-2909.108.2.171

Meyer J. P., Allen, N. J., \& Smith, C. A. (1993). Commitment to organizations and occupations: extension and test of a three-component conceptualization. Journal of Applied Psychology, 78(4), 538-551. http://dx.doi.org/10.1037/0021-9010.78.4.538

Meyer, J. P., Stanley, D. J., Herscovitch, L., \& Topolnytsky, L. (2002). Affective, continuance, and normative commitment to the organization: a meta-analysis of antecedents, correlates, and consequences. Journal of Vocational Behavior, 61(1), 20-52. https://doi.org/10.1006/jvbe.2001.1842

Meyer, J. P., Stanley, D. J., Jackson, T. A., McInnis, K. J., Maltin, E. R., \& Sheppard, L. (2012). Affective, normative, and continuance commitment levels across cultures: a meta-analysis. Journal of Vocational Behavior, 80(2), 225-245. https://doi.org/10.1016/j.jvb.2011.09.005

Mincer, J., \& Higuchi, Y. (1988). Wage structures and labor turnover in the United States and Japan. Journal of the Japanese and the International Economies, 2(2), 97-133. https://doi.org/10.1016/0889-1583(88)90017-2

Ministry of Economy, Trade and Industry (METI). (1997). 31st survey of trends in business activities of foreign affiliates (in Japanese). https://www.meti.go.jp/statistics/tyo/kaigaizi/result/result_10.html

Miyamoto, M. (2007). Changes in corporate governance and reform of human resource management (in Japanese). In Japan Institute for Labour Policy and Training (JILPT). Japanese companies and employment. https://www.jil.go.jp/institute/project/series/2007/05/index.html

Moriguchi, C. (2014). Japanese-style human resource management and its historical origins. Japan Labor Review, 11, 58-77. https://www.jil.go.jp/english/JLR/documents/2014/JLR43_moriguchi.pdf

Mobley, W. H. (1977). Intermediate linkages in the relationship between job satisfaction and employee turnover. Journal of Applied Psychology, 62(2), 237-240. https://psycnet.apa.org/doi/10.1037/0021-9010.62.2.237

Mowday, R. T., Steers, R. M., \& Porter, L. W. (1979). The measurement of organizational commitment. Journal of Vocational Behavior, 14(2), 224-247. https://doi.org/10.1016/0001-8791(79)90072-1 
Nakane, C. (1972). Japanese society. University of California Press.

Newburry, W., \& Thakur, P. (2010). Multi-level impacts on perceived career opportunity from global integration: human capital development within internal institutional environments. International Journal of Human Resource Management, 21(13), 2358-2380. https://doi.org/10.1080/09585192.2010.516591

Ono, A. (1989). Traditional practices of Japanese-style employment and the labor market (in Japanese). Toyo Keizai.

Ono, A. (1995). Promotion and wage structure in the firm (in Japanese). Hitotsubashi University research series, economics, 36, 3-101.

Ono, H. (2007). Careers in foreign-owned firms in Japan. American Sociological Review, 72(2), 267-290. http://dx.doi.org/10.1177/000312240707200207

Ono, H. (2010). Lifetime employment in Japan: Concepts and measurements. Journal of the Japanese and International Economies, 24(1), 1-27. https://doi.org/10.1016/j.jjie.2009.11.003

Organisation for Economic Co-operation and Development (OECD). (1973). OECD reviews of manpower and social policies 11: Manpower policy in Japan.

OECD. (1996). OECD employment outlook 1996. https://doi.org/10.1787/empl_outlook-1996-en

OECD. (2006). OECD economic Survey: Japan 2006. https://doi.org/10.1787/eco_surveys-jpn-2006-en

Porter, L. W., Steers, R. M., Mowday, R. T., \& Boulian, P. V. (1974). Organizational commitment, job satisfaction, and turnover among psychiatric technicians. Journal of Applied Psychology, 59(5), 603-609. https://psycnet.apa.org/doi/10.1037/h0037335

Pudelko, M., \& Harzing, A. W. (2008). The golden triangle for MNCs: standardization towards headquarters practices, standardization towards global best practices and localization. Organizational Dynamics, 37(4), 394-404. https://doi.org/10.1016/j.orgdyn.2008.07.002

Rusbult, C. E., \& Farrell, D. (1983). A longitudinal test of the investment model: the impact on job satisfaction, and turnover variations in rewards, costs, alternatives, and investment. Journal of Applied Psychology, 68(3), 429-438. http://dx.doi.org/10.1037/0021-9010.68.3.429

Sanchez, R. (1995). Strategic flexibility in product competition. Strategic Management Journal, 16(S1), 135-159. https://doi.org/10.1002/smj.4250160921

Sano, Y., Morishima, H., \& Seike, A. (Eds.). (1997). Frontiers of Japanese human resource practices. Japan Institute of Labour.

Scholl, R. W. (1981). Differentiation organizational commitment from expectancy as a motivational force. Academy of Management Review, 6(4), 589-599. https://doi.org/10.4236/psych.2018.91003

Scott, S. G., \& Bruce, R. A. (1994). Determinants of innovative behavior: a path model of individual innovation in the workplace. Academy of Management Journal, 37(3), 580-607. https://doi.org/10.2307/256701

Seibert, S. E., Kraimer, M. L., \& Liden, R. C. (2001). A social capital theory of career success. Academy of Management Journal, 44(2), 219-237. https://doi.org/10.2307/3069452

Sekimoto, M., \& Hanada, M. (1987). Organizational commitment and its influence factor (in Japanese). Industrial and Organizational Psychology Research, 1(1), 9-20.

Spence, M. (1973). Job market signaling. Quarterly Journal of Economics, 87(3), 355-374. https://doi.org/10.2307/1882010

Steel, R. P. (2002). Turnover theory at the empirical interface: problems of fit and function. Academy of Management Review, 27(3), 346-360. https://doi.org/10.2307/4134383

Tan, D., \& Rider, C. I. (2017). Let them go? How losing employees to competitors can enhance firm status. Strategic Management Journal, 38(9), 1848-1874. https://doi.org/10.1002/smj.2630

Tanaka, A. (2015). Wage premiums for exporters and multinational enterprises: Evidence from Japanese linked employer-employee data. Discussion papers 15106, Research Institute of Economy, Trade and Industry (RIETI). https://www.rieti.go.jp/en/publications/summary/15090001.html

Tsui, A. S., Pearce, J. L., Porter, L. W., \& Tripoli, A. M. (1997). Alternative approaches to the employee-organization relationship: Does investment in employees pay off. Academy of Management Journal, 40(5), 1089-1121. https://doi.org/10.2307/256928 
Vandenberg, R. J., \& Lance, C. E. (2000). A Review and synthesis of the measurement invariance literature: Suggestions, practices, and recommendations for organizational research. Organizational Research Methods, 3(1), 4-69. http://dx.doi.org/10.1177/109442810031002

Wang, H.C.., He, J., \& Mahoney, J. T. (2009). Firm-specific knowledge resources and competitive advantage: The roles of economic- and relationship-based employee governance mechanisms. Strategic Management Journal, 30(12), 1265-1285. http://dx.doi.org/10.1002/smj.787.

Williams, L. J., \& Hazer, J. (1986). Antecedents and consequences of satisfaction and commitment in turnover models: A reanalysis using latent variable structural equation methods. Journal of Applied Psychology, 71(2), 219-231. https://psycnet.apa.org/doi/10.1037/0021-9010.71.2.219

Williamson, O. E. (1975). Markets and hierarchies: Analysis and antitrust implications. Free Press.

Wright, P. M., McMahan, G. C., \& McWilliams, A. (1994). Human resources and sustained competitive advantage: A resource-based perspective. International Journal of Human Resource Management, 5(2), 301-326. https://doi.org/10.1080/09585199400000020

Yoshihara, H. (Ed.). (1994). Foreign-owned firms in Japan (in Japanese). Dobunkan.

Zaheer, S. (1995). Overcoming the liability of foreignness. Academy of Management Journal, 38(2), 341-363. https://doi.org/10.2307/256683

\section{Copyrights}

Copyright for this article is retained by the author(s), with first publication rights granted to the journal.

This is an open-access article distributed under the terms and conditions of the Creative Commons Attribution license (http://creativecommons.org/licenses/by/4.0/). 